\title{
FUNDAMENTALISM: POWER AND THE ABSOLUTE
}

\author{
Heinrich Schäfer ${ }^{2}$
}

\section{Introduction}

Ministers and teachers of theology seem to be the ones who lead the Church into error, and the more these are paid, the longer vacations they have, the higher positions they obtain, the more unfaithful to God and his church they seem to become. $^{3}$

And thus - as the same author underscores at another place - they betray a considerable body of truths "which are always true and which are everywhere recognized as true by rational minds". 4

These historical quotations of the fundamentalist Charles Blanchard already show us important elements of classical evangelical fundamentalism in the USA around the turn of the century: it considers itself to have a scientific basis and to be in accord with unalterable, eternal truths and with the valid common sense of the general public.

I am supposed to give you a "conservative evangelical perspective" on fundamentalism. This does not come easily to me. I did indeed go through the "conservative evangelical position" in the course of my life: in 1975 I was converted from the Roman Catholic Church in a Pentecostal evangelical environment. But in the interval I have moved on to an ecumenical theology

1 Edited and abridged version of a paper presented at the Consultation on Fundamentalism, World Alliance of Reformed Churches, Mülheim, Germany - February 22-26, 1993.

2 The author spent two years in Guatemala and Nicaragua to do research on Pentecostalism, resulting in a Ph. D. thesis (under supervision of Dr. Konrad Raiser). At present he is pastor at Marl, Germany, and teaches Ecumenics at Bochum.

3 Charles Blanchard, "The coming of the Lord draws near", in Prophetic Conference Addresses Given at the Winona Lake Bible Conference, Winona Lake, IN, 1918, p. 207; quoted in George M. Marsden, Fundamentalism and American Culture. The Shaping of 20th Century Evangelicalism, 1870-1925, New York, NY: Oxford University Press, 1980, p. 220.

4 Blanchard, Psychological Foundations. Unpublished manuscript, Wheaton College Archive, p. 28 and passim, quoted in Marsden, op. cit., p. 219. 
which does perhaps share one element or another with Pentecostal or charismatic theology and piety, but only a little with a "conservative evangelical perspective". In what follows I should nevertheless like to express a certain sympathy for what is commonly called fundamentalism by drawing cautious distinctions on the phenomenon. The focus of what I have to say will lie in systematic considerations relating to historical material. The underlying thesis is that in fundamentalism we have to do with a religious strategy to gain, or regain, perspectives for action in a crisis situation. ${ }^{5}$ This strategy

1) starts by identifying its supporters with the absolute;

2) makes an exclusive claim to truth and validity;

3) aims as far as possible to bring whatever differs from it wholly under its dominion (this is important for the drawing of fine distinctions); and

4) has to be distinguished from escapism.

Underlying this thesis is the observation that all religious fundamentalisms have a common substructure. In what follows I shall briefly illustrate what this structure is by an analysis of evangelical fundamentalism and exemplify it in charismatic fundamentalism. But I am pretty certain that this structure is to be found also in Catholic, Islamic or Hindu fundamentalism. In my view, different emphases in the contents can be traced back to different soteriological points of departure or situations - in sociological terms, to a different religious demand. My thesis implies that not everything which shocks liberal minds is fundamentalism; rather that the criterion of the claim to power ${ }^{6}$ and its transformation in practice helps us to distinguish a fundamentalism, which I think is theologically illegitimate, from an "escapism" - a retreat from the world, so to say - which may rather be conceived as theologically legitimate on the background of the apocalyptic tradition in the Bible. In the analysis of the evangelical tradition in the USA this difference will become apparent in differing ideas of history as expressed by premillennialism and dispensationalism.

\section{Classical Fundamentalism in the USA}

First of all I shall demonstrate the process by which fundamentalism

5 By "crisis" I mean a situation in which the reproduction of a system, taken for granted in everyday-life, becomes questionable and the system no longer has at its disposal enough possibilities to make it meaningful and permit action to safeguard its own continued existence.

6 Here the term "power" embraces the implementation of one's own will in terms of its recognition by those who are dominated (i.e. "domination") and also by means of compulsion, cf. Max Weber, Wirtschaft und Gesellschaft [Economics and Society], Tübingen: Mohr, $1985^{5}$, pp. 28, 122 and 544. Fundamentalist praxis includes both possibilities. 
absolutizes its own position on the basis of a soteriological starting-point of crisis; I shall then go on to speak about the main thematic emphases of fundamentalism in the USA at the turn of the century.

\section{Absolutizing one's own position}

Fundamentalism in the USA goes back further than just the twenties of this century. Its theological roots lie in the nineteenth century: on the one hand in the premillenialist movement and on the other in the "Princeton theology" which had a Reformed basis. For real fundamentalism however the Princeton theology is determinative rather than premillenialism. ${ }^{7}$ Corresponding to this, the premillenialism which is directly "faithful to the Bible" had its roots more in the white lower classes while academic Princeton theology and likewise the fundamentalism of the twenties of our century were the preoccupations of the religious Establishment and the middle classes. In this connexion the fundamentalist eschatological doctrine of "dispensationalism" - which, as is well-known, includes premillenialism - is in fact an interesting indication of the difference between millenialism and fundamentalism. But I shall have something to say on this later.

7 Ernest R. Sandeen, The Roots of Fundamentalism. British and American Millenarianism. 1800-1930, Chicago, IL: University of Chicago Press, 1970, derives fundamentalism from millenialism. In Darby we can already see a close connection between the two. I should like however to go along with Marsden's reservation in regard to the sponsors of the fundamentalist coalition of the twenties of our century - "that it is doubtful that premillenialism was really the organizing principle even in their own thought" (Marsden, op. cit., p. 5). A cautious modification of Sandeen's thesis can be advocated on the one hand for systematic reasons which will emerge from the reflexions in these pages, and for historical reasons on the other - Marsden discusses Sandeen's research results and distinguishes in fundamentalism the broad militant anti-modernist evangelical coalition of the twenties and a separatist and dispensationalist fundamentalism of our own day. $\mathrm{He}$ claims that in regard to the former and its origins Sandeen's derivation of fundamentalism from the millenialism of the nineteenth century is too narrow, but that it is appropriate as regards the latter. (Cf. even somewhat more critically on this point the earlier investigation by George Marsden, "From Fundamentalism to Evangelicalism: A historical analysis" in David F. Wells/John D. Woodbridge (eds.), The Evangelicals, Nashville, TN/New York, NY: Abingdon, 1975, p. 126). Sandeen's researches are frequently picked up in the literature, but in this millenialism is mostly given a subordinate role as a secondary strand of tradition in the fundamentalism of verbal inspiration. The current view may be held to be that the specific element in fundamentalism is the postulate of verbal inspiration and the inerrancy of the Bible (cf. Wilfried Joest, article "Fundamentalism" in Theologische Realenzyklopaddie, vol. 11, Berlin/New York, NY: deGruyter, 1983, p. 733, whofollowing Sandeen - points beyond the academic interweaving of the dogma of Scriptural inerrancy to its use in millenialism also) and to the fact that it goes beyond the Princeton Theology by still finding room for the strand of a "prophetic chiliasm" and a charismatic spiritual piety (James Barr, article "Fundamentalism" in Evangelisches Kirchenlexikon, vol. 1, Göttingen: Vandenhoeck \& Ruprecht, 1986, column 1405). 
Fundamentalism in the USA was born of the social and economic upheavals of the nineteenth century. The theologies generally attributed to fundamentalism have different emphases in different social classes. Common to all of them, however, are two characteristics: On the level of form they allow the believers to dissociate themselves from the situation of crisis they are experiencing; and on the level of content, they adopt a specific and appropriate theological theme that contrasts with their specific form of crisis. Those themes differ between the various groups according to the social status of their adherents.

The white lower and lower middle classes of the northern states found the second half of the nineteenth century to be a radical change of everything that had previously existed. The identity of these whites of the USA, had been progress-oriented and founded on simple Bible piety. It suffered its first wounds as a result of the Civil War and was sorely tested by swift industrialization and urbanization. The "promised land", as it had been in the colonial period and after the attainment of independence, was in danger of drowning in the tide of modernity and new waves of immigrants. The white Americans, who had not benefited from developments, became strangers in their own home. Especially among those who were hardest hit by the changes a need now spread to find a point of certainty, a rock in the current of change. This was the Bible which, taken as it stood, offered itself to scientifically unreflective, naïve biblicism as the old truth that remains as valid as ever, and as a refuge. But here the main emphasis for believers lay more in the fact that the Bible offers certainty of not being swallowed up by the wave of change, and less in its role as a guarantee of absolute knowledge.

The evangelical theological elites, on the other hand, also had their problems with the changes of their times. But they were much more concerned about changes in theology and philosophy than about economic and social change. In the USA Anglo-Saxon empiricism of the Baconian type had established itself as the basic scientific paradigm in theology as in the rest of science. Above all in theology it had entered into a symbiosis with the "common sense" philosophy originated in Scotland. This conspectus made it possible, for instance, to continue asserting the existence of God as a principle evident to everyone, even with the presuppositions of an empiricist tendency in the sciences. Thus it was possible to conceive of the Bible as a "book of facts" - facts which ought to be clear for everyone. This position was subjected to vigorous competition through the definitive breakthrough of Enlightenment rationalism, historical consciousness and the theory of evolution. The rationalism of the Enlightenment confronted Scripture with general truths of reason as criteria of truth. Historical consciousness recognized a cleft between the Bible as a historical document and the situation of its readers. This recognition is now understood as interpretation, no longer as the assimilation of the matter with the ideas one had of it. Naturalism simply denies any working of God in the world and traces everything back to the operation of nature itself. And finally 
Darwin crowns the scenario by postulating chance, selection and change as the constitutive elements for the whole of nature and by equating the "crown of creation" with the fool of creation. As against that, the evangelical theologians sought to defend Scripture, as those new doctrines threatened first of all to carry the maelstrom of the historicity of existence over the rocks of eternal truth. Secondly the new theories did not agree with "common sense" in the USA - at any rate not yet in the nineteenth century. And thirdly, many evangelical theologians regarded the new theories as unscientific, as they did not share the empiricist ideal defined by Francis Bacon.

What happened then can rightly be described with George Marsden - using Thomas Kuhn's term - as a "paradigm shift" in the humanities. Thus the fundamentalists were not anti-scientific or even anti-intellectual; they simply judged "the standards of the later scientific revolution by the standards of the first - the evolution of Bacon and Newton". ${ }^{8}$ For many theologians Scripture and faith in any case depended on the validity of the old scientific paradigm and Scripture and faith were for evangelicalism simply the decisive factor.

The theological debate was taken up above all in the Presbyterian Princeton Seminary, NJ, around the middle of the 19th century. The work there starts from the (relatively general) fundamentalist basic consensus that - in George Marsden's words - "knowledge of truth was of overriding and eternal significance, that truth was unchanging, and that it could be known by true science and common sense". 9

What view of the theological approach to knowledge lies behind this? The empiricist concept of reason is the crucial medium for theological knowledge. Reason is in a position to discern the facts of Scripture clearly in detail and to analyse them and produce from them - empirically - general pronouncements on the matters dealt with in Scripture. Accordingly the Bible takes on the role of a compendium of facts for theological and scientific data. Alexander A. Hodge, one of the theologians in Princeton, wrote that "all the affirmations of Scripture of all kinds whether of spiritual doctrine or duty, or of physical or historical fact, or of psychological or philosophical principle, are without any error". ${ }^{10}$ All these facts, the natural and the "supernatural", are accessible without distortion to reason; and reason works empirically. This all-embracing empiricism gives Princeton theology the opportunity to come to a conclusion a minore ad majus: if in fact it can be shown that the biblical statements on natural, historical and other empirically verifiable data are correct, then it can be deduced that statements on spiritual, "supernatural" data

8 Marsden, op. cit., p. 214.

9 Marsden, Fundamentalism and American Culture, p. 216.

10 A.A. Hodge/B.B. Warfield, "Inspiration", in Prebyterian Review 2, 1881, p. 238 quoted from Sandeen, op. cit. p. 126. 
are also correct.

With this combination of empiricism and supernaturalism ${ }^{11}$ fundamentalists justify a conceptual realism, the contents of which no longer need to be confirmed by "common sense" but must simply be demonstrated empirically in Scripture. Conceptual realism starts from the idea that what is meant by a concept has real existence. It does not distinguish between the sign and the thing signified and thus it hypostatizes the meaning. The idea - which is described by Nicolai Hartmann as tempting ${ }^{12}$ - that conceptuality and the principle of existence are identical gives fundamentalism the opportunity to attribute an objective reality in the ontological sense to the empirically knowable biblical concepts. They acquire this existence in a supernatural world - a world that is there "above" the natural world - the elements of which are (we must perhaps say) mirrored in the concepts of the Bible. For dyed-inthe-wool fundamentalists the "Kingdom of God" is thus a different supernatural reality from the "Kingdom of Heaven". ${ }^{13}$ For fundamentalism, therefore, a supernatural reality, a something, an essence - strictly speaking a substantia - is concealed behind every concept. The "facts of salvation" are thus really objectified. In this way the empirically rational reading of Scripture makes possible a direct insight into the supernatural kingdom of divine realities. But if concept and object are unified in this way, then from an epistemological and ultimately also an ontological - point of view continuity and not difference prevails between the natural and the supernatural world, between human beings and God, between the relative and the absolute. In more pointed theological terms, fundamentalist epistemology and ontology relativize the absolute and identify it with the contents of the fundamentalist's own understanding. Thus, these human beings claim for their own cognition to be

11 "Dispensationalist thought was characterized by a dual emphasis on the supernatural and the scientific": Marsden, op. cit. p. 55, cf. also pp. 66ff. An example is Cyrus I. Scofield (ed.), The Holy Bible. The Scofield Reference Bible, New York, NY: Oxford University Press, 1945, on 2 Thess. 2:3: he bases an exegetical decision on the idea that "a 'mystery' always implies a supernatural element".

12 Cf. Nicolai Hartmann, Der Aufbau der realen Welt, 1940, pp. 108f., in a critique of the realist position in the debate on universals in the Middle Ages. Conceptual realism in fundamentalism differs from the realism of the early scholastics above all by the fact that it attributes real existence not only to universals but to the most diverse concepts.

13 Cyrus I. Scofield, for example, says that "the kingdom of heaven is the earthly sphere of the universal kingdom of God..." (Scofield, op. cit., on Matthew 6:33). John Walvoord, an important more recent representative of this tendency relates the kingdom of heaven "to nominal Christianity, the kingdom of God only to true Christians" (John Walvoord, Thy Kingdom Come, Chicago: Moody Press, 1955, p. 30 as quoted in George Eldon Ladd, "Aus der Sicht des historischen Prämillenarismus (Zum Dispensationalismus)" in Robert G. Clouse (ed.), Das Tausendjährige Reich, Marburg: Francke, 1983, p. 78). Others, again, relate the two concepts to different phases of the eschaton. (It can be seen that the supposed realities are nevertheless treated once again as concepts which are filled out differently by different interpreters!) 
absolute, and for their own initiative what is believed to be God's initiative in Christ: the identification of God with humanity.

Talk about the infallibility and inerrancy of Scripture finds a place in this context, and with it the doctrine of verbal inspiration. On the one hand, as regards content, this theory makes the facts that have been ascertained immune to criticism. But to me it seems more important that infallibility ultimately legitimizes the absolute position of the knowers and likewise lends immunity from criticism. The thesis of infallibility is thus quite simply the final safeguard in absolutizing one's own position. Dialogue about the contents of what is discovered is from then on no longer either possible or meaningful; what counts for fundamentalists is the successful promotion of what is held to be true, by means of techniques of domination.

With this form of theological knowledge, of course, more takes place than the mere scholarly defence of Scripture and common sense as opposed to a novel doctrine. Strictly speaking the fundamentalist theologians liberate themselves even from common sense itself by taking this step, but without dropping the claim to the scientific nature and general validity of their own theories. On this basis it can be asserted - as we learned from Charles Blanchard's pen at the beginning of this address - that common sense is subject to deception by malicious "ministers and teachers of theology" when it no longer corresponds to fundamentalist views. Moreover, the claim of the fundamentalist world view to dominate society remains intact, even though it does not correspond to common sense, whereas without this epistemological theory it would in fact be bound to correspond to common sense. In the last analysis, of course, this detachment of fundamentalism from common sense expresses simply the progressive marginalization of fundamentalism since the first world war; common sense had turned against fundamentalism, as Marsden explains. ${ }^{14}$

So much for the formal operation of absolutizing one's own knowledge.

\section{The central theological issues}

The central theological issue is that particular theological subject-matter which deals thematically with the most important religious demand of the believers. The central theological issue thus corresponds most directly to the soteriological point of departure of the believers. It establishes religious meaning for the situation people are living in. Formal absolutizing simply reinforces the persuasive power of this theological meaning.

The soteriological situation of the poor whites was characterized by the 
anomical developments in modernization that were described above. For the victims of modernization the Civil War and the ensuing upheavals destroyed the optimism of post-millenialist eschatology which was still widespread in the first half of the nineteenth century. That eschatology had considered that in "God's own country" the Kingdom of God on earth could also be realised through continuous progress. In contrast, in the second half of the nineteenth century, the victims of radical social changes experienced a radical loss of prospects for the future and therefore for action. Shipwrecked hope and burning despair now made plausible an eschatological doctrine premillenialism - which proclaimed that the righteous would soon be taken up - rapt - from a world which is becoming progressively more evil. Premillenialism, like post-millenialism, is focused on change; it is conceived in terms of the movement of history towards its fulfilment in the near future and - like postmillenialism - it understands history as a process which is open in itself but oriented towards a goal. Only - unlike the post-millenialists premillenialists do not consider the present as a fertile field onto which the seed of the Kingdorn of God needs only to fall for it to spring up at once; rather, they find the present a desert which destroys every kind of life and accordingly they await their "rapture" or translation out of misery into heaven at the return of Christ and the inauguration of the thousand years' Kingdom of Christ by Christ himself. This change is the hope of those who are hopeless; the premillenialists await change impatiently.

In contrast, the non-liberal Establishment evangelical theologians, and with them sections of the middle and upper classes, became irritated by a new model of thought which legitimated the rapid social change, fostered social action, and questioned the stability of their social and scientific positions. This new paradigm geared around the idea of history as an evolutionary process. Thus, fundamentalists shaped their theological system in contradiction to the new central theme of the new scientific paradigm: the historicity of all being, which includes the relativity and transformation of human beings, of their works, of nature and even of God's revelation. ${ }^{15}$

The interest of the academic fundamentalists in change (or: non-change) as a theme of theology is only superficially similar to that of the premillenialists from the lower classes, although it makes use of a theological model which is very similar to premillenialism: dispensationalism. But in the last analysis the issue is in my view a different one. The similarity between premillenialism and dispensationalism does indeed tell us that in the USA the historical boundaries

15 At this point let me make a comment for the sake of the clarity of the argument: communication of the content of the formal process might also look completely different in other contexts with other challenges and here it is related only by chance to the phenomenon of change too. The debate might also be directed against secularism, economic decline or something similar. 
between the two were fluid. Nevertheless there were also significant conflicts - for instance that which led to the disruption of the Premillenialist Niagara Bible Conference by Dispensationalists (Scofield and Gaebelein). ${ }^{16}$ The real difference between premillenialism and dispensationalism is in my view that in dispensationalism we have to do not primarily with an eschatological but with a hermeneutical system. It is an answer to the concept of historical change as a presupposition of all understanding, as that concept had established itself in historical critical biblical scholarship. The fundamentalist theologians saw the notion of historical change as the fundamental problem for empiricist access to Scripture, and tackled it directly through dispensationalism. Recognition of the historical nature of the Bible tradition cannot of course be countered only by asserting the verbal inspiration of the documents. One must be able to respond to practical problems with the exegesis of Scripture - such as the problem that (as James Barr puts it) "what Jesus says is not the same as what Paul says, [and (HS)] that the gospels have a different theological role from the epistles $\ldots . .{ }^{17}$ This is precisely the question that historical critical understanding can answer, whereas fundamentalism runs into difficult problems of harmonization. Today, therefore, large elements of the theology that has its roots in fundamentalism have also taken over elements of historical criticism, especially in Germany, ${ }^{18}$ at the risk of endangering conceptual realism and infallibility. But it is all the more significant that the important current of dispensationalism has stubbornly set its face against this tendency up to the present day.

To solve the problems of understanding engendered by the notion of historical change, dispensationalism - adopting premillenialist thinking and using an empirical method - organizes the history that is told in the Bible in epochs. It then applies these to the biblical documents as different interpretative points of reference. In this way it succeeds in cancelling out historical change in the fundamentalist epistemology by means of a metaphysical model of history itself. ${ }^{19}$ According to Cyrus I. Scofield, the leading dispensationalist in the

16 Cf. Marsden, op. cit., pp. 52 and 241 n. 17, also Norman C. Kraus, Dispensationalism in America. Its Rise and Development, Richmond, VA: John Knox Press, 1958, pp. $99 \mathrm{ff}$. The question of when the "rapture" was to be expected is still vigorously discussed today, cf. Archer, Gleason L./Paul D. Feinberg/Douglas J. Moo/Richard R. Reiter, The Rapture. Pre-, Mid-, or Post-Tribulational?, Grand Rapids, MI: Zondervan, 1984; and Robert Clouse (ed.), op. cit.

17 James Barr, Fundamentalism. Philadelphia PA: Westminster Press, 1977, p. 198.

$18 \mathrm{Cf}$. on this e.g. Manfred Marquard: "Strukturen evangelikal-fundamentalistischer und traditionalistischer Theorie und Frömmigkeit", in Reinhard Frieling (ed.), Die Kirchen und ihre Konservativen, Göttingen: Vandenhoeck \& Ruprecht, 1984, p. 94.

19 This doctrine goes back to the Briton John Nelson Darby. Darby himself spread this doctrine in 1859 and 1874 in travels in the USA. There it spread quickly and, as an interpretative approach, was the basis of the Scofield Reference Bible. The principles leading to knowledge are on each occasion theological prejudgments on the meaning and function of specific historical epochs. They free the view which depends on dispensationalism from the need to enter into discussion on the significance of historical 
USA, the system of epochs represents "the progressive order of the divine dealings". ${ }^{20}$ Here the different epochs only serve as prior theological decisions or interpretative points of reference for understanding specific passages of Scripture. In the words of Norman Kraus, the expert on dispensationalism, the "coherence of Scofield's dispensational system is not historical or organic, but theological and schematic. It becomes historical only by virtue of being superimposed on the historical narrative". ${ }^{21}$ Correspondingly, the emphasis lies not on historical progression but on the fact that people in every epoch, and from each corresponding different point of reference, are tested by God - and always fall short. Thus this theory certainly offers "a rationale of change", as Gordon Melton says. ${ }^{22}$ But in the first place, it does not have to look on its own method of understanding as itself historically capable of change, but can stay within its empiricist conceptual realism; secondly it interprets historical upheavals, especially the struggle for social justice, as the immediate consequence of human sin, and sees history as the eternal return of the same thing - testing and failure.

Dispensationalism tries to depict history as a system in order to put a deadlock on history. It does not simply oppose a premillenialist pessimism to the optimistic liberal theology of progress but negates history as a process that is open in itself, though preserving the concept of history in a static metaphysic of history, the system of epochs. At this point, one can note a convergence of the formal absolutizing of dispensationalism's own position by means of epistemology and the debate over the most important question of the age addressed to the fundamentalists: in line with the epistemology of conceptual realism, "history" now means the prefiguration of the temporal - a prefiguration which "really", substantially exists in the supernatural world and can be perceived in the Bible. The Bible as a "book of facts" is now the exact time-table for events. What predominates here is not the dynamic of despair and hope, as in premillenialism, but the cool knowledge of objectified facts. By means of the system of dispensationalism, empiricist supernaturalism has objectified and eliminated the principle of general relativity of all beings: historicity. This combination of elements of content and form makes the dispensationalist fundamentalism of the turn of the century a truly brilliant model of antiliberal thinking.

The observation that the urgency of eschatology is lost through its objectification in dispensationalism is confirmed by the fact that dispensationalism stretches out time. While premillenialism sees itself mostly

conditions for the meaning of the text.

20 Scofield, op. cit., p. III.

21 Kraus, op. cit, p. 115.

22 J. Gordon Melton, Encyclopedia of American Religions, 2 vols., Wilmington: McGrath, 1978, p. 413. 
as already in the midst of the "great tribulation" and imagines the rapture of the church and/or the return of Christ to be very close at hand, the dispensationalist system places a phase of successful world mission and the rapture of the church before the beginning of the "great tribulation". The dispensationalists do not feel (so much) that they are sufferers; they do not discern (such a strong) urgency, and they stretch out the period till the "rapture" or the return of Christ. The period of time gained from this theological transaction is then defined as an opportunity to turn the religious claim to power into a reality by world evangelism. The establishment of historical time to act by dispensationalist theology thus correlates directly with a social claim to validity - and that means, to power.

\section{The claim to power}

As far as I can see, fundamentalism of the dispensationalist tendency is, sociologically, an option of professional theologians and people from the middle and even upper classes who saw their social position endangered by social upheavals and scientific change. Over against that they wanted to absolutize their own theological and social position and legitimize it as the only valid one, and to stigmatize change in the status quo as $\sin$. In fundamentalism, therefore, a relatively privileged social position gives itself an absolute status and tries to assert its claim to mould society as it sees fit, using all available resources. The well-known public debates of the twenties provide an eloquent testimony to this.

I think that an important difference between fundamentalists and premillenialists becomes clear in the question of power. The difference can be established by linguistic analysis and sociologically, and results from the soteriological point of departure of premillenialist believers and the theologians closely allied to them. (What I say below cannot be asserted in the same way in regard to academic premillenialist theologians who do not share this point of departure. $)^{23}$ From a situation of despair those believers place their sole and ardent hope on Christ's coming soon. With this pressing question in mind they also read the Bible, and do so in a biblicist way. Only they simply do not trouble themselves about thorough systematizing or even dogmatizing, let alone about the empirical completeness of the facts that are analysed. Nevertheless their attitude is to forbid any watering down of the expectation of Christ's coming by historical-critical limitations; this would not be compatible with their life-situation of despair. Hence observers of these movements mostly note fundamentalist features in them.

23 The debate between dispensationalists and premillenialists in the volumes edited by Archer, Feinberg, Moo and Reiter (op, cit.) or Clouse (op. cit.) - simply to single out arbitrarily two titles from the great mass of literature - is at all events purely academic. 
But the language of the premillenialists is not pre-eminently diagnostic or confirmative like fundamentalist language, but performative: it seeks to make the return of Christ present as hope in despair. This language is to be found subject to a small reservation which I shall explain further on - in the linguistic field which the German theologian Reinhold Bernhardt has described as one having a legitimate claim to religious absoluteness; namely where the claim to absoluteness "discloses that it is not giving expression to neutral statements of fact, the truth of which is to be asserted with reasons that are open to general inspection, nor descriptive affirmations of facts that go back to supposedly objective findings, but rather an expressive, evocative, motivating discourse, as registering an inspiring total experience, where the claim does not seek to be objective or informative language in the context of science, philosophy and dogmatics, but personal or community confession, witness, doxology". ${ }^{24}$ However, this language can change its character into that of a factual statement, and it can be manipulated as well. The difference between the doxologies of escapism and the statements of fundamentalism is not always easy to perceive, but it is nevertheless important.

This brings us to the reservation I mentioned above. It concerns the selfawareness of the speaker. For one can hardly presuppose a theological "knowledge about the inappropriateness in principle of language in relation to God" ${ }^{\prime 25}$ among the premillenialists as a reflexive state of consciousness. They seemed rather to persist in a (pre-modern) naiveté as regards the problems of knowledge. This fact does not mean that their language is not an "expressive, evocative, motivating form of discourse" (Bernhardt). But it is bound up with the danger that the almost inevitable straying into epistemological awareness takes a short-cut through fundamentalist conceptual realism; and this would mean that intensive premillenialist piety would not encounter the paradigm of historical change which corresponds to it more genuinely than does the rigidity of dispensationalism.

The fact that genuinely premillenialist groups do not use common sense as an a priori basis to make their own discourse plausible also argues for a nonfundamentalist basic attitude among them. The holy remnant's truth of faith is not in fact directly apparent for the massa perditionis nor does it make any claim to be in accord with the rationality of the "world". Nor do the groups put themselves tentatively in the way of conflict with science but they tell the world what threatens it. They do indeed deny theological legitimacy to the "evil world" but do so on the basis of a knowledge of faith which is not in itself capable of communicating with the world. They withdraw from the debate and make no claim to hegemony - religious, cultural or political - in

24 Reinhold Bernhardt, Der Absolutheitsanspruch des Christentums. Von der Aufklärung bis zur Pluralistischen Religionstheologie. Gütersloh, Mohn, 1990, p. 238.

25 Bernhardt, ibid. 
society. Sociologically speaking, the claim to absoluteness by premillenialist groups, which has a kind of confessional character, is therefore also transformed only into a strategy for the reconquest of the narrowest kind of "life-world"26 and this goes along with the goal of surviving with human dignity in the existing structures - till the ardently longed-for "rapture" comes! Thus in practice the claim to absoluteness does not make itself felt as a claim to power over others on the part of these groups but, on the contrary, as the freedom not to be kept under the power of others.

Fundamentalists, on the other hand, do not place premillenialist hope of change at the centre of their religious system but Scripture as such, combined with a claim to absolute knowledge in theology as well as in science. The empiricist concept of science as well as theology, together with their claim to dictate common sense inevitably leads fundamentalists into a conflict with secular science and other social forces concerning the power to define what, in society, is acknowledged to be real and true. Similarly, on the level of theological content, a conflict concerning the power to define social reality was equally inevitable. At the turn of the century, evolutionism had already become common sense in the USA and served both the capitalism of the sharks as a social-darwinist legitimation and the Social Gospel movement as a philosophical theory for social reform. Against this social and philosophical background, however, some evangelical and fundamentalist preachers and theologians gained repute in circles within the economic elites and became more closely involved with them; this was perhaps because industrialists had quickly realised that evangelism rallies among their workers were an excellent alternative to strikes (which were frequent at that time) and to socialist organizing. At the same time the Social Gospel movement tried to cope theologically with evolutionism in a creative way and became a potential rival to evangelical and fundamentalist preachers among the poor masses. Theologically, the combination of progress and social improvement by reform in Social Gospel represented the exact opposite of the dispensationalists' deadlocking of history. Social Gospel turned into the main enemy for fundamentalists. The stretching of time in dispensationalist eschatology (in contrast to premillenialist urgency) provided the fundamentalists with the necessary religious-symbolic space for this conflict, while the timetable for the future believed to be contained in the Bible made them feel secure as to the outcome of the battle.

26 The terms Lebenswelt ["life-world"] and Welt ["world"] - dependent on the use of the term "Lebenswelt" in sociology, which derives from Husserl's phenomenology - mean here the everyday world in the broadest sense, with its seemingly unquestionable economic, social and political relations, in contrast to abstract science which reflects on itself. The terms are not of course limited to the specific individual (je meinige) ranges of experiences or only to the immediately visible everyday world of the man in the street, but include social structures and processes; the "Lebenswelt" is always also a situation or position in the field of social struggles. 
In the "roaring twenties", when conservative evangelicalism and common sense were definitely no longer one, the latent conflict concerning the power to define the social concept of reality (and thus the reality of social life) erupted into open war. Fundamentalists drew the frontline between themselves, as the genuine Christian and American force on the one hand, and atheist reformers and revolutionaries, on the other. The latter were to be eliminated under fundamentalist leadership in order to save the USA from perishing. Thus fundamentalists claimed to represent the only valid religious, political and social position in the US and beyond it at that time. The claim to absoluteness and to total social power, the attempt to eliminate opponents by means of power rather than to convince them by argument, and the identification of religion and national culture merged into one model of political religion. The legitimizing and manipulative use of religious falsehood in the electoral campaigns of 1984 and 1988, or even Jerry Falwell's or Pat Robertson's way of dealing with their religious and political opponents, show the model still at work among recent fundamentalists in the USA.

From these reflexions follows a differentiation within what is commonly described as fundamentalism. This rests on a narrow definition of fundamentalism which includes both (a) the absolutizing of one's own position and (b) an epistemological and social claim to validity which really is implemented in practice and can also be erected into a claim to social power. This differentiation implies that absolutizing one's own position without this claim to power should not really be described as fundamentalism but rather as escapism.

The borderline between the two naturally cannot always be clearly drawn especially when we become clear about the different transformational possibilities of social claims to power. Thus for instance an escapist attitude in a crisis situation which is relevant for a whole class can be of great comparative advantage for the group of people concerned: they can perhaps conserve their strength by not investing it in risky social projects, but by investing it - with a relative advantage over other people in the same situation - in their own advancement or their own security. In this way escapism also helps towards the expansion of social power over others: it enables its supporters to accumulate economic or social capital ${ }^{27}$ in a social situation where such an accumulation is not possible for comparable social groups. Nevertheless it can be noted that even in the case mentioned we do not have to do with a social claim to validity and power actually made good by the escapists, but rather with an objective consequence of their escapist tendency.

27 On these different forms of capital cf. Bourdieu, Pierre, "Ökonomisches Kapital, kulturelles Kapital, soziales Kapital" in Reinhard Kreckel (ed.), Soziale Ungleichheiten, Göttingen: Schwarz, 1983, pp. 183-198. (= Soziale Welt: Sonderband, Special issue, 2.) 


\section{Summary}

I hope that I have been able to make the following aspects of fundamentalism clear with this brief trip through history:

a) Formally, the empiricist view that the reality itself can be distinguished directly and correctly, together with conceptual realism, allows fundamentalists to identify their own position with the absolute and thus to absolutize it over against other theological and social positions.

b) In regard to content, dispensationalism takes up the central thematic challenge of the new scientific paradigm, "the historicity of being", by modifying the old paradigm only slightly. Here the gain for fundamentalism is to express the - in principle - unchangeable nature of truth, and of their own position in particular, in a theological model which superficially resembles the new scientific paradigm. Historical change is in the last analysis condemned to stand still.

c) Functionally speaking, fundamentalism serves respectively to articulate and establish a specific social position, the interests that correspond to it, and its claims to power over against other social positions. At this point we have to distinguish between an upper middle and upper class fundamentalism with claims to social power, on the one hand, and a lower class escapism claiming only survival in dignity, on the other.

\section{Fundamentalism versus Escapism: the Illusion of Time}

In a variety of ways we have thus noted differences between fundamentalism and a theology of flight from the world, (which I call escapism). We have been able to recognize the crucial difference in the matter of the claim to power in the relation to the world. This difference, however, is not simply a problem of ethics; rather it has a deeper dimension with theological relevance. This is revealed when we enquire about the different ways in which time is experienced and is dealt with theologically.

We had seen that fundamentalist dispensationalism, as distinct from premillenialism, takes urgency away from the early expectation of the end, and stretches time out. But if conversely we see the loss of opportunities for action as a time-loss in the teeth of a threat, then the patent solutions and instructions for action promptly offered by fundamentalism seem like a gaining of time. Here in most instances it is a question of an illusion of time, because the recipes offered rest less on an analysis of the crisis and its conditions than on a religious representation of the interests of those who belong to the particular social sub-system confronted with the crisis. Thus, in the first instance we 
have to do with a subjective gain of time which has been earned at the cost of analysis of the causes of the crisis, and thus at the cost of a potential alienation. And whether the subjective gaining of time ends up in a mere distraction from the heightening crisis or whether it can be transformed into an effective surmounting of the crisis in line with the interests of those involved depends on two factors: first, the fundamentalist religious system must - at least in outline - represent the causes of the crisis in religious terms; secondly the fundamentalists in question must command such a favourable social position that they are objectively in a position to undertake action that is at least more or less relevant. But notwithstanding this, the subjective impression of having time at one's disposal in regard to the crisis is linked to the idea of having prospects for action. Consequently this impression of having time tends to establish a claim for the validity of one's own tentative solutions over against society and thus to be transformed ultimately into a claim to power. ${ }^{28}$ Fundamentalist alchemy thus transforms the theologically produced illusion of a surplus of eschatological time into a strategy for power as regards the shaping of the world. In dispensationalism this transformational alchemy takes the concrete form of turning the expectation of the immediate coming of the eschaton into the imperative for world mission. The shortness of time in the immediate expectation of the eschaton is replaced by the prospect of conquering space and thus increasing one's own symbolical and social power (Bourdieu). The well-known argument that world mission must therefore be rapidly initiated because Christ will return only when the whole world has heard his message carries this transformation to the extreme: it eliminates time as the leading principle of eschatology and establishes the category of space understood in terms of the question of power (the "space of hegemony" if you like) - as the governing principle. Here, once again we see that with dispensationalism we have to do not with an attempt at fundamental transformation but with the maintenance of the conditions of the "life-world" as it is, i.e. of the status quo.

Premillenialist escapism on the other hand theologizes the experience of crisis wholly in the category of time. The radical loss of prospects for action makes itself felt as an equally radical loss of time in relation to the feared catastrophe. The theological figure of hope in such a situation is the direct, almost immediate expectation of the "rapture" - translation - out of the scenario of crisis and so a confirmation and legitimizing of the loss of time and of the prospect for action which has been experienced. This theological treatment of the crisis experience is pushed to extremes in the well-known argument that the world can only get worse and worse till Christ comes again. In fatalism the category of time is fully dominant over the relation of human

28 This can be observed very effectively in the transformation (described above) of the postponement of the eschaton into a programme for world mission such as dispensationalism undertakes. 
beings to the world and is so in the denial of the prospects for action - and when all is said, in a denial of the world itself. In this eschatology, the category of space - especially space in the form of power - is swallowed up in that of time. The supporters of this eschatology take their bearings entirely from the fundamental change of all conditions of life, to which however they think that they themselves cannot contribute anything. But in escapist groups the radical relation to time and change leaves open a great many more possibilities for these groups themselves to change and find their way to ecumenical openness than is the case in real fundamentalism. These possibilities of self-change are to be found wherever prospects of social action present themselves which open up a seemingly realistic prospect of overcoming the crisis.

What we know of Old Testament prophecy at the time of the Israelite monarchy is a religious option in the face of crises, which is opposed to fundamentalism and premillenialism but is not wholly dissimilar to them. The proclamation of judgment creates real, objective time by the very fact that it diminishes subjective time. But as distinct from premillenialism it does not wholly deny time and includes possibilities for social action in its calculations. The significant difference from fundamentalism lies in the fact that by diminishing subjective time the prophetic reaction to crises promotes in its supporters an objective focus on problems, while fundamentalism promotes its supporters' objective focus on power through a subjective gain in time (which in some circumstances is illusory).

\section{Different Fundamentalisms: e.g. Charismatics}

The absolutizing of religious experiences and views and also the strategy for the symbolic (re)conquest of the world are communicated in different cultural and social spheres by way of different contents taken from the stock of symbols in an appropriate religious tradition. These contents become relevant in line with the particular challenges which fundamentalism has to deal with. Thus as intermediaries, sacred scriptures like the Bible, the Koran or the Vedas come just as much into consideration as other sources of revelation, such as the Holy Spirit, or the special position of the head of a church or the like. The function of the contents is subordinated to that of the structure, resulting in a great diversity of religious fundamentalisms.

Here however we can already make a few reservations. These rest on the connexion between the claim to absoluteness and the claim to power. What picture emerges if we apply this criterion to the worldwide increase in the fundamentalism that comes from - in the broadest sense - the Reformation tradition? According to current ideas, more or less every new religious movement which carries on evangelistic campaigns and creates a great stir - 
promising healing or asserting eternal truth under an ephemeral authority, splitting from the old and founding new congregations and churches - comes under suspicion of being fundamentalist.

But if we look more closely into this it will be easy to draw distinctions. The supposed fundamentalism of many groups is really nothing of the kind. Rather it is a matter of a religious option for physical, psychological and cultural inviolability in the face of threatening social developments and alien domination - for example that of western culture in relation to churches in countries of the Third World. For many of these churches the claim to absoluteness could well be the only language for their own situation which matches the intensity of the felt threat, and with which the Third World can tell people of the North Atlantic in a way they will understand that they have had to pray long enough in the way the North prayed but no longer want to listen. Most of the African independent churches will belong to this type but so too will innumerable small Pentecostal churches under national leadership throughout the world, and also the most diverse revivalist groups. Here we may regard it as a "dialectic of the counter-enlightenment" (thus the Berlin ethnologist Juliana Stroebele-Gregor) ${ }^{29}$ where the last-mentioned churches have emerged from a fundamentalist mission tradition and have grown into a new openness to their own societies and their problems; only in this context we have to note that this recovery of enlightenment must not be confused in any way with our western rationality but on the contrary leads not infrequently to conscious new approaches in thought and action in the traditions of the nonEuropean cultures.

On the other hand I do consider fundamentalist most of the great societies of the "western mission" who, as reactionary cultural Protestantisms, want to assert their vision of the world and their claim to power in religion, politics and culture with a large deployment of capital. Here we may mention Bill Bright's evangelical Campus Crusade for Christ and likewise the charismatic organization Youth with a Mission and Pat Robertson's (700 Club) television empire; and similarly the Pentecostalist Reinhard Bonnke, "God's Harvester in Africa". They are all fundamentalist even if their fundamentalism is imparted through different theologies.

To develop this last thought more fully - fundamentalism in different garments - let me give a brief sketch of fundamentalism in the charismatic movement, as an entity which is to be distinguished from evangelical fundamentalism.

29 Juliana Ströbele-Gregor, Dialektik der Gegenaufklärung. Zur Problematik fundamentalistischer und evangelikaler Missionierung bei den urbanen Aymara in La Paz (Bolivien). Bonn: Holos, 1988. 
We find, then, a specific development of fundamentalism in the charismatic movement. Of course I do not mean the charismatic movement as a whole but a specific current. In no sense can we call the Pentecostal charismatic approach in the religious experience of the Holy Spirit fundamentalist as such. But it offers possibilities of a fundamentalist interpretation which are undoubtedly realised in some currents of the charismatic movement. On this matter I shall be paraphrasing, quoting and commenting on a book entitled "Come Holy Spirit" by Larry Christenson ${ }^{30}$ in order to describe this position, although not all the contributions underlying Christenson's compilation have a fundamentalist tendency.

Generally the starting point in charismatic fundamentalism is an experience of the "empirical reality" of God in religious experiences, leading to a "knowledge of the supernatural". The religious experiences are of an ecstatic nature and communicate a feeling of identification with the Holy Spirit. In this experience the empirical natural world and the supernatural world (thought of in real terms) meet. This is the basis of a supernatural insight into the realities of God, his plans etc.

Here the soteriological starting point of believers is that they see their social advancement as having been assaulted and called in question. They feel at home in society in general, but at the same time feel that they are endangered by certain special occurrences. This situation is presented in the panorama of the supernatural world by the contrast between spirit and demons. Fundamentalist charismatics then place themselves on the side of the Spirit and outline their praxis as "spiritual warfare" in accordance with a "biblical world view", against the others who are excluded as demonic. While this fundamentalism communicates its claim to absoluteness through the semantic opposition, "Spirit versus demon", it brings the social contrast into the centre of its theological system in a religiously transfigured way. It thus not only achieves the total disqualification of its opponents but also pre-eminently this: exorcism, the driving out of demons by the representatives of the Spirit, establishes itself as the supreme model of action on the most varied levels of praxis, from the religious through to the political. Here the conquest of the world takes place by the expulsion of the others.

\section{Prosperity Gospel and Neoliberalism: Economics of Fundamentalism}

It is in line with a contextual view of systematic theology to consider the social location of the theological systems one is examining or developing as relevant for their meaning. Accordingly I should like to draw attention here to a few

30 Larry Christenson, Komm Heiliger Geist. Informationen, Leitlinien, Perspektiven zur Geistlichen Gemeindeerneuerung, Metzingen/Neukirchen-Vluyn: Ernst Franz/Aussaat, 1989. 
structural correspondences between modern US fundamentalism and the neoliberal model of the economy.

Fundamentalism asserts its claim to dominion over the whole of society. The symbolical benefits of salvation, however, are distributed only within the sphere of fundamentalist dominion and only to those who submit wholly to the logic of the system - those who make their symbolical, social and economic capital function wholly within the system of fundamentalism. It is all one, whether the accent lies more on the claim to absoluteness in the internal domain, as in evangelical fundamentalism, or more on the readiness against danger from external sources, as in charismatic fundamentalism. A strict boundary between the internal and the external domains divides those who belong to the system and partake of the benefits of salvation from those who fall outside the logic of the system and so outside the distribution of its benefits. An encompassing unity and harmony are unimaginable; harmony arises only within the system through the exclusion of deviationists. The means of entry into the system are important for establishing the dividing line between outsiders and insiders: voluntary conversion (decision) on the basis of rational recognition of the objective truth of the fundamentalist system. Conversely the conclusion is drawn from this that those who do not belong in the system have themselves to blame and so do not even have a claim to the benefits of salvation which fall as crumbs from the master's table (after the fashion of "anonymous Christianity" or the apokatastasis pantōn [restoration of all things]). Contrariwise: according to the fundamentalists, any suggestion that salvation might be possible outside the system, without a decision, lulls the outsiders into false security and discourages them from pursuing their entry into the system. To distribute the benefits of salvation gratuitously is counterproductive - both for the system and for those gratuitously favoured. Consequently the winners must not allow the losers to benefit in any way.

With this logic, evangelical and charismatic fundamentalism alike show that they are religious equivalents to particularly clear-cut forms of neoliberal economic theory. These too - on the basis of the analysis by Franz Hinkelammert of the works of Milton Friedmann, Friederich von Hayek, Alvin Toffler and others - make the boundary between those cooperating in the system and profiting from it and those who do not belong to it a fundamental structural element of their theories and models for praxis, without explicitly saying so.

Basic to the post-modern variant of neo-liberalism (...and an important difference from "ordo-liberalism") advocated by (for example) Toffler is the principle that the market is in a position to regulate all economic and social relations. The market is total; as Hinkelammert says, it is simply the "reality of rationality". In connexion with the capacity of the market for regulation Friedrich von Hayek continues to assert the older postulate that what happens 
in the market tends to a general equilibrium. A general harmony, according to this, is produced as all active persons conform to the laws of the market. ${ }^{31}$ Those who are excluded from what happens in the market must therefore try to integrate themselves into the market-system. This of course is not always possible and according to Hinkelammert presents itself more and more clearly as a postulate which is just as untenable as that of the market's tendency to equilibrium. And now on top of that, in the light of the collapse of socialism, young neoliberals in particular no longer feel the need to assert a comprehensive principle of justice for themselves. This supposed absolutizing of one's own approach helps some of them towards a fundamentalist directness. In the case of Toffler for example the contrast between inside and outside, power and the lack of it, the rationality of the system and irrationality, becomes constitutive and is expressed as such:

This is the fast economy of tomorrow. It is the accelerative, dynamic new wealthmachine that is the source of economic advances. As such it is the source of great power as well. To be de-coupled from it is to be excluded from the future. Yet that is the fate facing many of today's 'less developed countries' ... This means that slow economies will have to speed up their neural responses, ... or drop out of the race entirely. ${ }^{32}$

Extra mercatum nulla salus! [No salvation outside the market!] And those who drop out of the system have themselves to blame. Thus help for those who are not fast enough - and Hayek would entirely agree here ${ }^{33}$ - would be counter-productive both for this group of people and for the whole. Even worse: such help would be an interference in the laws of the market, and in the rationality of the system itself, which as in fundamentalism, is indeed the reality of all rationality. The "world market is the world's judgment" - as Hinkelammert sums the matter up. ${ }^{34}$

If we start from the idea that economic, political and religious systems function at least partially in tune with each other, fundamentalism is an ideology which represents important structures of the neoliberal model for the economy in religious terms.

31 "He (Hayek) calls for a total market which follows only its own principles" (Hinkelammert, Utopie und Ethik, San José, unpublished, n.d., p. 39). According to what Hayek himself says, what matters here is that "justice [Gerechtigkeit] is not of course a matter of the aims of an action but of its conformity with rules to which it is subject" (quoted in the above) - i.e. the rules of the market.

32 Alvin Toffler: "Toffler's next shock. A dramatic 'powershift' is coming, and all nations face one inescapable rule - survival of the fastest." In World Monitor, Nov. 1990, pp. 34-44, especially here in pp. 36/38; quoted from Hinkelammert, op. cit, p. 40 .

33 Cf. Hinkelammert, op. cit. p. 41.

34 ibid., p. 41. 
In the first place this tallies with the fact that neoliberal capitalism and fundamentalism both began to dominate public debate at the same time in the seventies. Moreover, not a few fundamentalists underscore with Jerry Falwell that "the free enterprise system is clearly outlined" in the Bible ${ }^{35}$. But it is also possible to verify a deep structural equivalence between fundamentalism and neo-liberalism where fundamentalism and economic thought have fused into one: in the "Prosperity Gospel" (or also "Positive Confession Theology", "Word of Faith" or "Faith Formula Theology"). This doctrine - writes Leonard Lovett ${ }^{36}$ - goes back to the father of the "New Thought philosophy" in the USA, the philosopher, occultist and spiritualist Pinehas P. Quimby (1802-1866). Today its centre of gravity lies in the postulate of an ontological continuity between God and humanity in its striving for prosperity; in the words of Kenneth Copeland, one preacher of prosperity, "you don't have God in you. You are one. "37 This identification with the absolute is the source of the "divine right" for the "children of God" - i.e. the supporters of the Prosperity Gospel - to possess the top-grade consumer goods and to be protected from the claims of the "demon of poverty"38 - thus profiting from the market and at the same time being able, as opposed to its victims, to claim legitimacy and protection. The situation of the victims - poverty - is on the contrary regarded as a consequence of unbelief, of dishonouring God and of the activity of demons. The absolutized area within the borders of the religion of Prosperity is thus linked to a claim on the world, namely consumer goods, and is equated to the inside area of the neo-liberal consumer society. The life inside follows its own laws, the "laws of prosperity" which do not hold good for those outside. The outsiders have themselves to blame and are unworthy either of grace or salvation: extra benedictionem nulla salus [no salvation apart from the blessing]. From this it follows that the outsiders are rather pushed further into their poverty as a result of material aid, and that instead of this they can make progress only by being subjected to the laws of the "inside". The basic structure of the Prosperity Gospel is thus revealed as a religious

35 Jerry Falwell: Listen America. New York, NY: Doubleday, 1980, p. 13.

36 Lovett, Leonard, article, "Positive Confession Theology" in Stanley M. Burgess/Gary B. McGee (eds.) Dictionary of Pentecostal and Charismatic Movements, Grand Rapids, MI: Zondervan, 1989. pp. 718-720.

37 Cf. ibid., p. 719. On ontological continuity of. likewise Lovett: Quimby, William Branham, E.W. Kenyon and John G. Lake developed the God-image which Kenneth Copeland, Kenneth Hagin, Charles Capps and Frederik Price are spreading today: "Man is not a separate creation detached from God, he is part of God himself ... God intends us to be Gods" (Lake). "Just as ...cats have kittens, so God has little Gods. Until we comprehend that we are little gods and we begin to act like little gods, we cannot manifest the kingdom of God" (Bishop Earl Paulk, Atlanta).

38 In Kenneth Copeland's words, "(God) wants his children to eat the best, he wants them to wear the best clothing, he wants them to drive the best cars, and he wants them to have the best of everything". Quoted from Paul Gifford, Christianity: To Save or to Enslave? Harare: Ecumenical Documentation and Information Centre of Eastern and Southern Africa, n.d., p. 7. 
complement to the neoliberal economies and their ethical implications. ${ }^{39}$ The Prosperity Gospel thus fulfils the function today of a legitimizing ideology for a fundamentalist and neo-liberal minority who is in an unjust state of prosperity, against the claims of its victims, the unwanted who clamour for a just share in economic opportunities. ${ }^{40}$ Thus Prosperity Fundamentalism under present-day conditions serves the purpose of maintaining economic power above all else.

Let us merely note another parallel between neo-liberal economic theory and fundamentalism: both of them are directed (explicitly or implicitly) against the traditional democratic and humanistic trends of modern times but they do make use of its technocratic trend.

\section{Conclusion}

At the beginning of fundamentalism in the USA stood concern for Scripture in the raging fires of modern reason. Out of this concern a strategy developed for the conquest or reconquest of theological and social stances. That strategy operates on the basis of identifying its sponsors with the absolute, raises an exclusive claim to truth, validity and domination and pursues the aim of subjecting whatever is different from its own specific features or even eliminating it.

In my view it is naturally of great importance to distinguish between a claim to absoluteness of knowledge and a claim to absoluteness in what is confessed. Just because a religious group turns a deaf ear to dialogue - a dialogue which an oppressed group feels to be in no way free of domination - it does not do to describe that group as fundamentalist when, in situations of oppression and marginalization, it advances the absolute certainty of its salvation over against the religious systems of the oppressors. On the contrary it seems to me that there is an urgent theological necessity to pay careful attention to the connexion between theological claims to absoluteness and ecclesiastical, social, political and cultural claims to power, in the great efforts at mission and evangelism which are at present being initiated in different confessions (including Roman Catholic) and by independent agencies.

On the other hand the vigorous increase in fundamentalism seems to me to be a challenge for the theologians and churches too. Less so, indeed, in the

39 Not incidentally Opus Dei also speaks of an "apostolate of non-giving"! Cf. Hinkelammert, "Vom 'humanistischen' zum 'wilden' Kapitalismus. Ein Gespräch mit Franz Hinkelammert", in Kreuz und Quer, vol. 11, 1992, no. 5/92, pp. 31-39, p. 33.

40 In this, the modern Prosperity Gospel differs from the gospel of prosperity of (for instance) a Russell $\mathrm{H}$. Conwell at the turn of the century. At that time the emphasis lay on the motivation to become a capitalist entrepreneur but less on legitimizing the status quo against the claims of the majority. Cf. Gifford, op. cit., pp. $8 \mathrm{f}$. 
academic field, although I believe it to be necessary to have a good knowledge of the phenomenon of fundamentalism. Perhaps there really is a grain of truth in the words of Charles Blanchard which I quoted at the start, that the "ministers and teachers of theology" distance themselves increasingly from the truth the more they establish their position in the dominant systems of the world. The most fruitful way in which churches and individual Christians may take up the challenge of fundamentalism is, at least in my view, to deepen our own spirituality and to radicalize our praxis in order to become more faithful and courageous disciples of the Galilean - in other words, to be "conservative" and "evangelical" in the best and most direct (but not in the most current) sense of the words.

(Translated from the German, Language Service, WCC) 
EXCHANGE -

JOURNAL OF MISSIOLOGICAL AND ECUMENICAL RESEARCH

EXCHANGE is a scholarly periodical published three times a year by the Interuniversity Institute for Missiological and Ecumenical Research (IIMO) in the Netherlands. It presents survey articles based on the extensive collection of Third World Christian periodicals and books available at the Department of Missiology in Leiden. A new development since 1987 is to participate in the theological discussion on current ecumenical topics. The Department of Ecumenical Research in Utrecht also pays attention to Russian Orthodoxy.

Editorial Board: Leny Lagerwerf (Editor), Anne-Jaap van den Berg, William van den Bercken, Martien Brinkman, Anton Houtepen, Marc Spindler and Karel Steenbrink.

Subscription: EXCHANGE, c/o IIMO-Dept. of Missiology,

Rapenburg 61, 2311 GJ Leiden, the Netherlands. Costs: Dutch Guilders 35,00 per annum. Single issues D.Gldrs. 13,00, excl. of postage. [tel.: 071-144248].

Barter agreements: Our aim is to exchange publications with theological colleges, institutes, and study centres in the Third World.

Payments:

- Dutch Giro A/c 1997239 payable to:

Directeur IIMO, afd. Missiologie, Rapenburg 61, 2311 GJ Leiden.

- Abroad: Upon receipt of invoice.

Indexes: Articles published in Exchange are indexed by:

- Bibliografia Missionaria (Rome)

- Bijeen Derde Wereld Index ('s-Hertogenbosch, Netherlands)

- Centre de Documentation et d'Information Missionnaire (Paris)

- International Review of Mission (Geneva)

- Missio Dokumentation und Information (Aachen, Germany)

- Missionalia (Pretoria, S. Africa)

- Religious Index One: Periodicals, American Theological Library Association, Evanston, available on line through BRS Information Technologies (Latham, NY) and DIALOG (Pala Alto, Calif.)

ISSN $0166-2740$ 


\section{CONTENTS}

$\begin{array}{ll}\text { Editorial } & \text { iii }\end{array}$

Fundamentalism: Power and the Absolute (Heinrich Schäfer) 1

Pentecostal Churches and Nicaraguan Politics - An Awakening 25

Love (Rommie Nauta/Hans Snoek)

Contemporary Millenianism and the New Age Movement 44 (Reender Kranenborg)

Turmoil in the Batak Church of Indonesia: Patronage as State

Policy (Karel Steenbrink)

Miscellanea

$\begin{array}{ll}\text { Book Reviews } & 84\end{array}$

$\begin{array}{ll}\text { Books Received } & 87\end{array}$ 